\title{
Comparative analysis of routes of immunization of a live porcine reproductive and respiratory syndrome virus (PRRSV) vaccine in a heterologous virus challenge study
}

Kang Ouyang 1,2, Jagadish Hiremath', Basavaraj Binjawadagi', Duan-Liang Shyu', Santosh Dhakal ${ }^{1}$, Jesus Arcos ${ }^{3}$, Rose Schleappi ${ }^{1}$, Lynette Holman ${ }^{4}$, Michael Roof ${ }^{5}$, Jordi B. Torrelles ${ }^{3}$ and Gourapura J. Renukaradhya ${ }^{1 *}$

\begin{abstract}
Porcine reproductive and respiratory syndrome (PRRS) is caused by PRRS virus (PRRSV), which infects primarily the respiratory tract of pigs. Thus intranasal (IN) delivery of a potent vaccine-adjuvant formulation is promising. In this study, PRRS-MLV (VR2332) was coadministered \pm an adjuvant Mycobacterium vaccae whole cell lysate or CpG ODN through intramuscular (IM) or IN route as a mist, and challenged with a heterologous PRRSV 1-4-4 IN at 42 days post-vaccination (dpv). At 14 and $26 \mathrm{dpv}$, vaccine viral RNA copies were one log greater in the plasma of PRRS-MLV IM compared to IN vaccinated pigs, and the infectious replicating vaccine virus was detected only in the IM group. In PRRS-MLV \pm adjuvant IM vaccinated pigs, reduced viral RNA load and absence of the replicating challenged virus was observed at 7, 10 and 14 days post-challenge (dpc). At $14 \mathrm{dpc}$, in BAL fluid $\geq 5$ log viral RNA copies were detected in all the pig groups, but the replicating challenged virus was undetectable only in IM groups. Immunologically, virus neutralizing antibody titers in the plasma of IM (but not IN) vaccine groups was $\geq 8$ against the vaccine and challenged viruses. At $26 \mathrm{dpv}$, PRRS-MLV IM (without adjuvant) received pigs had significantly increased population of CD4 and CD8 T cells in PBMC. At $14 \mathrm{dpc}$, relatively increased population of IFN- $\gamma^{+}$total lymphocytes, NK, CD4, CD8 and $\gamma \delta$ T cells were observed in the MLV-IM group. In conclusion, PRRS-MLV IM vaccination induced the virus specific T cell response in pigs, but still it is required to improve its cross-protective efficacy.
\end{abstract}

\section{Introduction}

Porcine reproductive and respiratory syndrome (PRRS) is a respiratory disease of pigs of all ages and a reproductive disease of sows. PRRS is an endemic disease in the swine industry worldwide [1], and causes approximately $\$ 664$ million losses annually in the USA [2]. PRRS virus (PRRSV) is the causative agent, isolated simultaneously in Europe and North America in the 1990s [3, 4]. PRRSV belongs to the Arteriviridae family [5] and displays a high genetic diversity [6]. To control PRRS, a

\footnotetext{
${ }^{*}$ Correspondence: gourapura.1@osu.edu

${ }^{1}$ Food Animal Health Research Program (FAHRP), OARDC, Department of Veterinary Preventive Medicine, The Ohio State University, Wooster, $\mathrm{OH} 44691$, USA

Full list of author information is available at the end of the article
}

modified live-attenuated PRRS vaccine (PRRS-MLV) has been widely used since the 1990s. PRRS-MLV protects pigs from clinical disease with reduced lung lesions [7] and viral shedding [8], and elicits a protective response against homologous virus. But apart from concerns about safety of PRRS-MLV in vaccinated pigs $[9,10]$, the breadth of cross-protection induced by MLV is highly questionable $[11,12]$.

Adjuvants are necessary to potentiate vaccine efficacy. Vaccine inoculated to a mucosal site along with a potent adjuvant upregulates the expression of costimulatory molecules on immune cells, which secrete chemokines and cytokines [13]. Mucosal vaccine coadministered through potent adjuvant/s induces superior cross-protective immunity by enhancing the array of antigen specific $\mathrm{T}$ and $\mathrm{B}$ cell responses; mediated by dramatic increase in 
spreading of antigenic epitopes and recognition of multiple conserved epitopes, which otherwise are not recognized [14-17]. Thus, the potency of adjuvant and delivery system determine the degree of cross-protection. PRRSV causes disease primarily in the respiratory tract and thus intranasal (IN) delivery of PRRS-MLV with a potent adjuvant is promising.

We have demonstrated that pigs vaccinated with PRRS-MLV intranasally with a potent adjuvant, Mycobacterium tuberculosis whole cell lysate (M. tb WCL), elicits better cross-protective immune response against heterologous challenge than without adjuvant [16]. But large-scale production of $M$. $t b$ WCL involves risk, time and cost, as $M . t b$ is a Biosafety Level (BSL)-3 agent. Alternatively, a non-pathogenic Mycobacterium (M. vaccae) adjuvant was shown to stimulate cytotoxic T-cell response [18] and provides protective response against tuberculosis [19]. Another vaccine adjuvant, CpG-oligodeoxynucleotide (CpG-ODN), activates the professional antigen-presenting cells [20] and potentiates the antibody and cross-reactive $\mathrm{T}$ cell response in mice $[21,22]$ and pigs $[23,24]$.

Therefore, in this study we evaluated cross-protective efficacy of PRRS-MLV coadministered with adjuvant M. vaccae WCL or CpG ODN through the IM or IN route. Our results suggest that those two adjuvants are not potent enough to augment the breadth of immunity against PRRS; rather PRRS-MLV delivered IM without any adjuvant is relatively better. Our results suggest that further studies are required to improve the cross-protective efficacy of PRRS-MLV using other highly potent adjuvants delivered IM and IN.

\section{Materials and methods Cells, PRRSV and adjuvant}

MARC-145 cells were used for growing PRRSV [25] and in immunological assays [26]. Cells were maintained in high glucose DMEM (HyClone, MA, USA) supplemented with $0.1 \mathrm{mM}$ HEPES (Fisher Scientific, NJ, USA), antibiotic/antimycotic solution (HyClone, UT, USA) and 10\% FBS (Atlanta Biologicals, GA, USA) at $37^{\circ} \mathrm{C}$ in a humidified atmosphere with $5 \% \mathrm{CO}_{2}$. DMEM containing $2 \%$ FBS was used to grow virus in MARC-145 cells. PRRSMLV was provided by Boehringer Ingelheim ${ }^{\circledR}$. A field PRRSV strain 1-4-4 isolated from infected sows in Ohio was used to challenge pigs. PRRS-MLV parent strain VR2332 and a genetically variant Type 2 PRRSV strain MN184 [27] were used to analyze the virus specific neutralizing antibody (NA) titers in plasma and BAL fluid samples. PRRSV ORF5 nucleotide sequence similarity between vaccine strain VR2332 and challenge stain 1-4-4 is $85.6 \%$. All the PRRSV were propagated in MARC-145 cells and aliquots were stored at $-80^{\circ} \mathrm{C}$ until use.

Mycobacterium vaccae (ATCC\#23027) was grown in endotoxin free $7 \mathrm{H} 9$ medium at $37^{\circ} \mathrm{C}$ in accordance with ATCC instructions, and the whole cell lysate (WCL) was prepared as previously described [28]. CpG ODN 2007 (TCGTCGTTGTCGTTTTGTCGTT) in phosphorothioate backbone was custom prepared (Integrated DNA Technologies, IA, USA). Five conserved T cell peptides of PRRSV, nsp10 (aa 2578-2628) CPGKNSFLDEAAYCNHL and (aa 2554-2604) VRILAGGWCPGKNSFLD; Nsp9 (aa 442-492) VRGNPERVKGVLQNTRF [29]; GP5 (aa 445-489) KGRLYRWRSPVIIEK [30]; and N (aa 187213) VRHHFTPSE [31] were custom synthesized (Thermofisher Scientific, NY, USA).

\section{Pigs and inoculation}

A total of 25 conventional Large White-Duroc crossbred 4 week old pigs were procured from The Ohio State University swine herd, which were seronegative for PRRSV, porcine respiratory coronavirus, transmissible gastroenteritis virus and porcine circovirus 2. Pigs were allowed to acclimate for a week before initiation of the experiment, and randomly divided into six groups $(n=4$ or 5 per group) (Figure 1A). Animals were maintained with

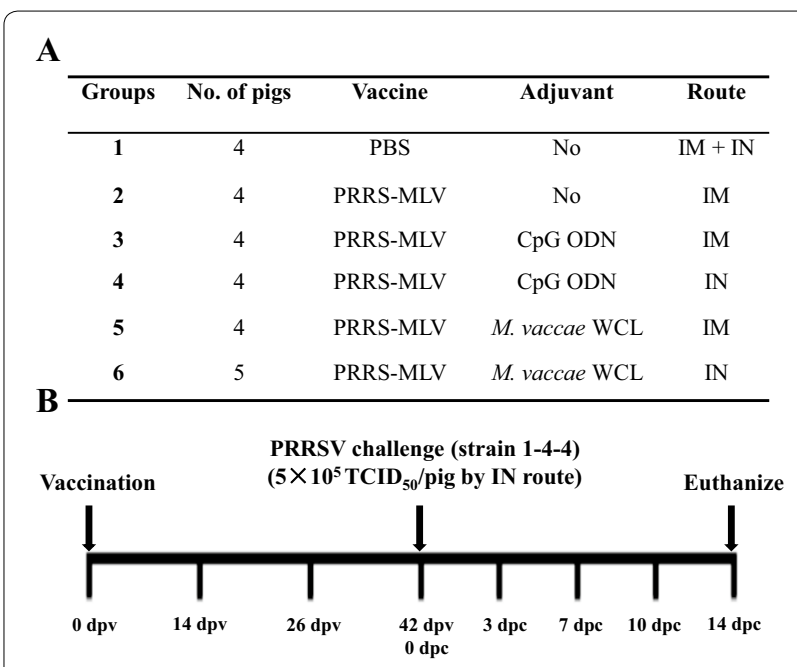

Figure 1 PRRS-MLV vaccination and challenge study work plan. A Conventional crossbred pigs were randomly divided into six Groups ( 4 or 5 per Group). PRRS-MLV was administered once without (saline) or with an adjuvant, M. vaccae WCL or CpG ODN, through intramuscular (IM) or intranasal (IN) route. B All the experimental pigs were challenged with a heterologous PRRSV strain 1-4-4 by IN route at $42 \mathrm{dpv}$. Blood samples were collected and rectal temperature and body weight were recorded at 0, 14, 26, $42 \mathrm{dpv}$ and 3, 7, 10, $14 \mathrm{dpc}$ and pigs were euthanized at $14 \mathrm{dpc}$. 
food and water ad libitum in our large animal BSL2 facility under the supervision of a veterinarian. The adjuvant (M. vaccae WCL $5 \mathrm{mg} / \mathrm{pig}$ or CPG-ODN $250 \mu \mathrm{g} / \mathrm{pig}$ ) and PRRS-MLV (the same vaccine dose as per the manufacturer's recommendation was inoculated either by IM or IN route) were not mixed for inoculation in pigs; and they were inoculated separately on either side of the neck through IM or IN to both nostrils as mist. The pig group vaccinated intranasally with PRRS-MLV without adjuvant was not included in this study, but such a group was included in our previous study [16]. Each pig received $2 \mathrm{~mL}$ vaccine formulation once, with $1 \mathrm{~mL}$ of vaccine/adjuvant to each side of the neck or each nostril. Pigs were challenged using a heterologous PRRSV strain 1-4-4 $\left(5 \times 10^{5} \mathrm{TCID}_{50}\right.$ per pig) on 42 days post-vaccination (dpv) IN as mist and euthanized on 14 days postchallenge (dpc) (Figure 1B). Rectal temperature and body weight of pigs were recorded during the experiment on the days of blood collection. Collection of samples, maintenance and euthanization of pigs were performed as per the approved animal use and care committee protocol of The Ohio state University.

\section{Collection of blood samples and bronchoalveolar lavage fluid of pigs}

For evaluation of viremia and PRRSV specific neutralizing antibody response, $5-7 \mathrm{~mL}$ of blood was collected at 0, 14, 26, $42 \mathrm{dpv}$ and 3, 7, 10,14 dpc. Plasma was separated using K2 EDTA plus blood collection tubes (BD vacutainer, NJ, USA) and preserved at $-80^{\circ} \mathrm{C}$ until use in the assays. At $26 \mathrm{dpv}$ and $14 \mathrm{dpc}$, peripheral blood mononuclear cells (PBMC) were isolated from blood collected in EDTA by gradient centrifugation using lymphoprep solution in sepmate tubes (Stem Cell Technologies, Canada) [32]. PBMC were resuspended in enriched-RPMI (E-RPMI, RPMI containing 10 \% FBS, $200 \mu \mathrm{m}$ HEPES, $1 \mathrm{mM}$ sodium pyruvate, $25 \mu \mathrm{m} 2$-ME, $1 \times$ Non-Essential Amino Acid, and $1 \times$ antibiotic and antifungal). Bronchoalveolar lavage (BAL) fluid was collected during necropsy as described previously [33] and aliquots were stored at $-80{ }^{\circ} \mathrm{C}$ until use in the assays.

\section{Virus and virus neutralizing antibody (NA) titration}

Analysis of PRRSV and NA titers in plasma and BAL fluids were performed by indirect immunofluorescence assay (IFA) [34, 35]. Briefly, for virus titration confluent monolayer of MARC-145 cells in 96-well microtiter plate was treated with 10-fold dilution of samples for $48 \mathrm{~h}$; for VNT, samples were heat $\left(56{ }^{\circ} \mathrm{C}\right.$ for $\left.30 \mathrm{~min}\right)$ and UV
( $254 \mathrm{~nm}$ for $45 \mathrm{~min}$ ) inactivated before use in the assay. Twofold serially diluted samples were incubated with equal volume of PRRSV (strain 1-4-4 and VR2332, 100 $\mathrm{TCID}_{50}$ per well; strain MN184, $200 \mathrm{TCID}_{50}$ per well) for $1 \mathrm{~h}$ at $37{ }^{\circ} \mathrm{C}$, and the mixture was transferred into microtiter plates containing a confluent monolayer of MARC-145 cells and incubated for $48 \mathrm{~h}$ at $37^{\circ} \mathrm{C}$. Cell plates were fixed using acetone-Milli- $\mathrm{Q}$ water (8:2) mixture for $10 \mathrm{~min}$ at room temperature $\left(\sim 20^{\circ} \mathrm{C}\right)$ and dried. Plates were treated with anti-PRRSV nucleocapsid protein specific monoclonal antibody (SDOW17) (Rural Technologies Inc., SD, USA) (1:10 000) for $2 \mathrm{~h}$ at $37^{\circ} \mathrm{C}$, followed by Alexa Fluor 488 conjugated goat anti-mouse IgG $(\mathrm{H}+\mathrm{L})$ (Invitrogen, CA, USA) secondary antibody (1:4000). The plates were examined under a fluorescent microscope after mounting with glycerol-phosphatebuffered saline (PBS) (6:4). The virus induced cytopathic effect was examined under a fluorescent microscope and the titer was calculated using the Reed and Muench method [34]. PRRSV titer was expressed as the 50\% tissue culture infective dose $\left(\mathrm{TCID}_{50}\right)$ per $\mathrm{mL}$. NA titer was the reciprocal dilution of the plasma or BAL fluid which caused $>90 \%$ reduction in virus-specific fluorescence foci compared to virus control well.

\section{Detection of PRRSV RNA load by qRT-PCR}

Plasma and BAL fluid samples were used in preparation of RNA by the MagMAX ${ }^{\mathrm{TM}} 96$ viral RNA isolation kit (Ambion/Applied Biosystems, CA, USA) [33]. RNA isolation was performed using $50 \mu \mathrm{L}$ of sample using the MagMAX $^{\mathrm{TM}}$ Express Magnetic Particle Processor (Applied Biosystems, NY, USA) according to the manufacturer's instructions. RNA was reverse transcribed into complementary DNA (cDNA) using Quantitect reverse transcription kit (Qiagen, Germany). The cDNA was used in real-time PCR reaction with PerfeCta SYBR Green Fast Mix (Quanta Biosciences, MD, USA) using the PRRSV ORF6 gene derived forward primer (GATAACCACG CATTTGTCGTC) and reverse primer (TGCCGTT GTTATTTGGCATA). Standard curves were generated using serial dilution of known copies of the PCR product. PRRSV RNA copies in each $\mathrm{mL}$ of plasma and BAL fluid were determined.

\section{Flow cytometric study of immune cell population}

Flow cytometry analysis was performed to determine the population of lymphocyte subsets from 50000 acquired events of immunostained PBMC [26, 33]. Briefly, PBMC isolated at $26 \mathrm{dpv}$ and $14 \mathrm{dpc}$ were plated $\left(5 \times 10^{6}\right.$ cells/ 
well) in 48-well tissue culture plate in the presence of PRRSV strain 1-4-4 $\left(5 \times 10^{4} \mathrm{TCID}_{50} /\right.$ well, $\left.0.01 \mathrm{MOI}\right)$ or pooled five PRRSV conserved peptides $(1 \mu \mathrm{g} / \mathrm{mL}$ of each peptide) in $1 \mathrm{~mL}$ E-RPMI for $48 \mathrm{~h}$ at $37{ }^{\circ} \mathrm{C}$ with $5 \%$ $\mathrm{CO}_{2}$, and cells cultured with E-RPMI medium only were included as a control. GolgiStop protein transport inhibitor (BD Bicoscience, CA, USA) and Goldiplug Brefeldin A (Sigma-aldrich, MO, USA) were added at the last $6 \mathrm{~h}$ of incubation [36, 37]. Cells were first surface-labeled using pig specific $\mathrm{mAb}(\mathrm{CD} 3 \varepsilon, \mathrm{CD} 4 \alpha, \mathrm{CD} 8 \alpha, \delta$ chain) conjugated with different fluorochromes [32, 38]. Subsequently, cells were fixed, permeabilized and stained for intracellular IFN- $\gamma$ using fluorochrome-conjugated mouse anti-pig IFN- $\gamma \mathrm{mAb}$ or its isotype control mAb (BD Biosciences, CA, USA). Immunostained cells were acquired using the BD Aria II flow cytometer and analyzed using the FlowJo software.

\section{Ethics statement}

This study was carried out in strict accordance with the recommendations by Public Health Service Policy, United States Department of Agriculture Regulations, the National Research Council's Guide for the Care and Use of Laboratory Animals, and the Federation of Animal Science Societies' Guide for the Care and Use of Agricultural Animals in Agricultural Research and Teaching. All the relevant institutional, state and federal regulations and policies were followed regarding care and use of animals at the Ohio State.

\section{Statistical analysis}

All data were expressed as the mean value of 4 or 5 pigs \pm SEM. Statistical analyses were performed using the GraphPad Prism 6 software by applying one way ANOVA followed by the Tukey's $t$-test. The statistical significance was considered at $P<0.05$.

\section{Results}

\section{Clinical outcome and PRRSV viral load in pigs}

Although we did not observe any respiratory distress in the experimental pigs, Group 3 (MLV-CPG IM), Group 4 (MLV-CPG IN) and Group 1 (PBS) pigs had moderate fever $\left(>40{ }^{\circ} \mathrm{C}\right)$ at 7 and $10 \mathrm{dpc}$ (Figure 2A). PRRSV titer $\left(\mathrm{TCID}_{50} / \mathrm{mL}\right.$ ) and RNA load (RNA copies/mL) in the plasma and BAL fluid were determined by qRT-PCR for PRRSV ORF6 and using MARC-145 cells for replicating infectious virus titers, respectively. In plasma, PRRSV
RNA copies in Group 2 (MLV-IM), Group 3 (MLVCPG IM) and Group 5 (MLV-Vac IM) pigs were 1-2 log higher compared to Group 4 (MLV-CPG IN) and Group 6 (MLV-Vac IN) at 14 and $26 \mathrm{dpv}$; and were 1-2 log lower at 7 and $10 \mathrm{dpc}$ compared to Groups 4 and 6 (Figure 2B). In pre-challenged pigs, the replicating vaccine virus was detectable only in IM but not IN vaccinated groups (Figure 2C). At $7 \mathrm{dpc}$, detectable infectious virus in all the IM pig groups was absent and the data were statistically significant compared to pig Group 1 (PBS) $(P<0.01)$ and Group 4 (MLV-CPG IN) $(P<0.05)$ (Figure 2D). The replicating virus was undetectable in the plasma of Group 4 (MLV-CPG IN) at $14 \mathrm{dpc}$ and at 10 and $14 \mathrm{dpc}$ in Group 6 pigs (Figure $2 \mathrm{C}$ ).

In the BAL fluid, $\geq 5 \log$ viral RNA copies were detected in all the pig Groups; in particular, all four pigs of Group 1 (PBS) and Group 4 (MLV-CPG IN) had high levels of RNA copies $(\geq 7 \operatorname{logs} / \mathrm{mL})$ with 1-2 log greater than the other groups (Figure 2E). The replicating virus was absent in BAL fluid of all the IM pig groups, while one or two pigs in both the IN vaccinated groups still had infectious virus (Figure 2F).

\section{Virus neutralizing antibody level in plasma and BAL fluid} PRRSV-specific NA titers in the plasma and BAL fluid against strains 1-4-4, VR2332 and MN184 were analyzed. In plasma, the NA titers against strains 1-4-4 and VR2332 were gradually increased in all the pig groups, and in IM vaccine groups the titers were two-fold higher than IN vaccine groups with mean titer $\geq 1: 8$ at 10 and $14 \mathrm{dpc}$ (Figures $3 \mathrm{~A}$ and $\mathrm{B}$ ). In contrast, NA titer against strain MN184 remained $<1: 8$ in all the tested pig groups (Figure 3C). In BAL fluid, the NA titers against the three tested viral strains were $<1: 8$ in most of the pig groups, and in Groups 5 and 6 against MN184 strain the NA titers were $>1: 8$ (Figures 3D-F).

\section{Phenotypic analysis of different T lymphocyte subpopulations in pigs}

The population of $\mathrm{CD} 3 \varepsilon^{+} \mathrm{CD} 4 \alpha^{-} \mathrm{CD} 8 \alpha^{+}$cells and T-helper/memory cells $\left(\mathrm{CD} 3 \varepsilon{ }^{+} \mathrm{CD} 4 \alpha^{+} \mathrm{CD} 8 \alpha^{+}\right)$in PBMC of Group 2 (MLV-IM), Group 5 (MLV-Vac IM) and Group 6 (MLV-Vac IN) pigs at $26 \mathrm{dpv}$ was significantly increased compared to Group 1 (PBS) (Figures 4A and B). Only MLV-Vac IM pig group had increased counts of $\gamma \delta$ T cells compared to PBS control (Figure 4C). The population of $\mathrm{CD} 3 \varepsilon^{+} \mathrm{CD} 4 \alpha^{-} \mathrm{CD} 8 \alpha^{+}$cells was significantly increased in 


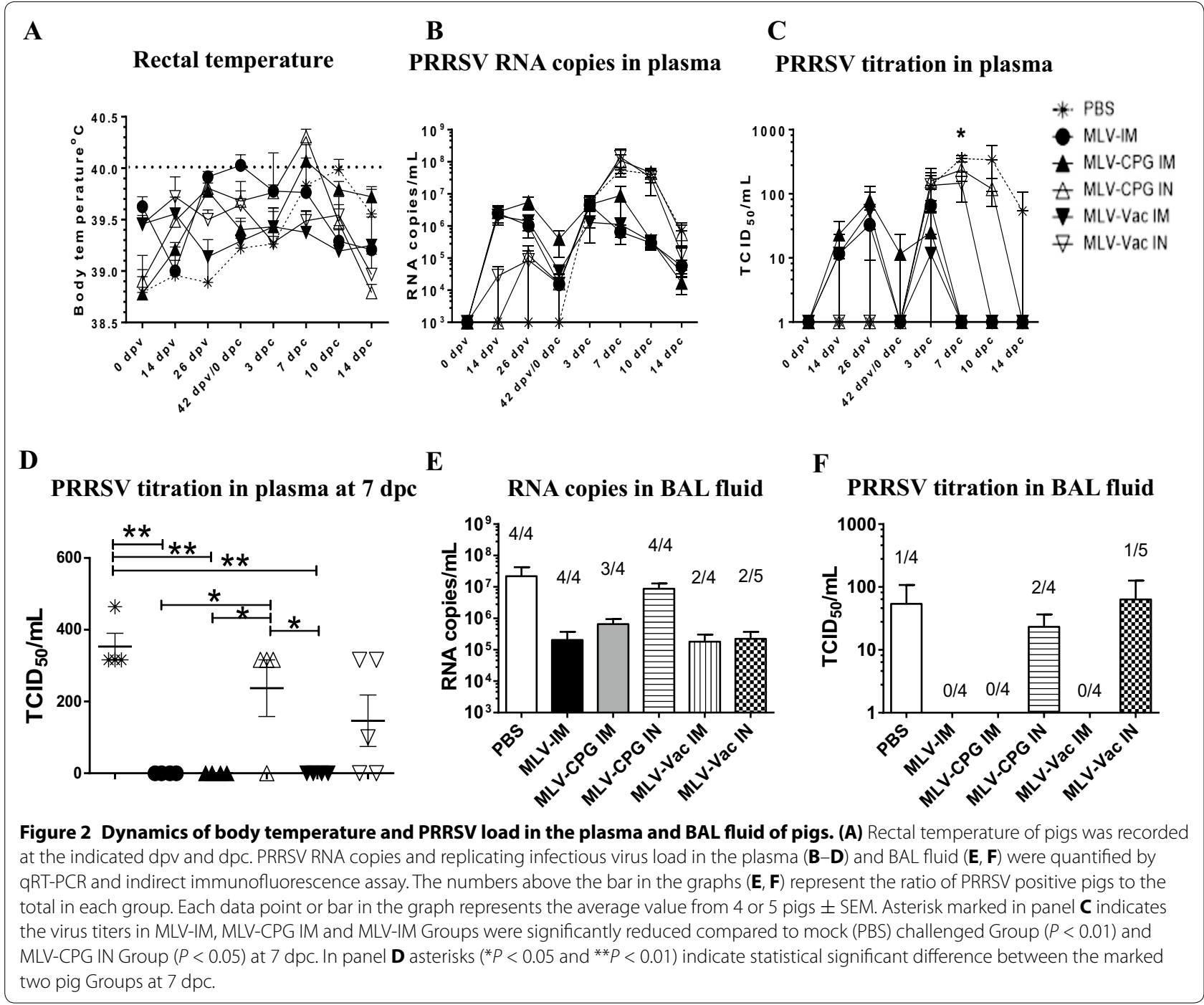

the MLV-Vac IN pig group restimulated with virus compared to peptide stimulation at $14 \mathrm{dpc}$ (Figure 4D).

At $26 \mathrm{dpv}$, none of the pig groups had increased activated $\left(\mathrm{IFN}-\gamma^{+}\right)$lymphocyte subsets (Figures $5 \mathrm{~A}-\mathrm{C}$ and $6 \mathrm{~A}-\mathrm{C})$. But at $14 \mathrm{dpc}$, significantly increased population of total and $\mathrm{CD} 3 \varepsilon^{+}$IFN- $\gamma$ secreting cells and IFN- $\gamma^{+} \mathrm{CD} 3 \varepsilon^{-} \mathrm{CD} 4 \alpha^{-} \mathrm{CD} 8 \alpha^{+}$(NK) cells were detected (Figures 5D-F). Also, IFN- $\gamma$ positive $\mathrm{CD} 3 \varepsilon^{+}$ $\mathrm{CD} 4 \alpha^{-} \mathrm{CD} 8 \alpha^{+}$(cytotoxic T cell $(\mathrm{CTL}) / \gamma \delta \mathrm{T}$ cell), $\mathrm{CD} 3 \varepsilon^{+}$ $\mathrm{CD} 4 \alpha^{+} \mathrm{CD} 8 \alpha^{+}$(T-helper/memory) and $\gamma \delta \mathrm{T}$ cells were observed in Group 2 (MLV-IM) pigs restimulated with the challenge virus ex vivo compared to control and other vaccine trial groups (Figures 6D-F).

\section{Discussion}

The restriction fragment length polymorphism (RFLP) code for the Type 2 prototype PRRSV strain VR2332 derived PRRS-MLV (Boehringer Ingelheim ${ }^{\circledR}$ ) was 2-5-2 [39], and it was passaged repeatedly in MARC-145 cells and became avirulent in pigs [32]. The RFLP code of the challenged field virus used in this study was 1-4-4, and it was widely prevalent in North America and has approximately $15 \%$ difference in amino acid sequence compared to VR2332 GP5 sequence [40]. Thus, we analyzed the efficacy of PRRS-MLV $\pm M$. vaccae WCL or CPG ODN administered IM or IN against the genetically heterologous viral strain 1-4-4 in pigs. 


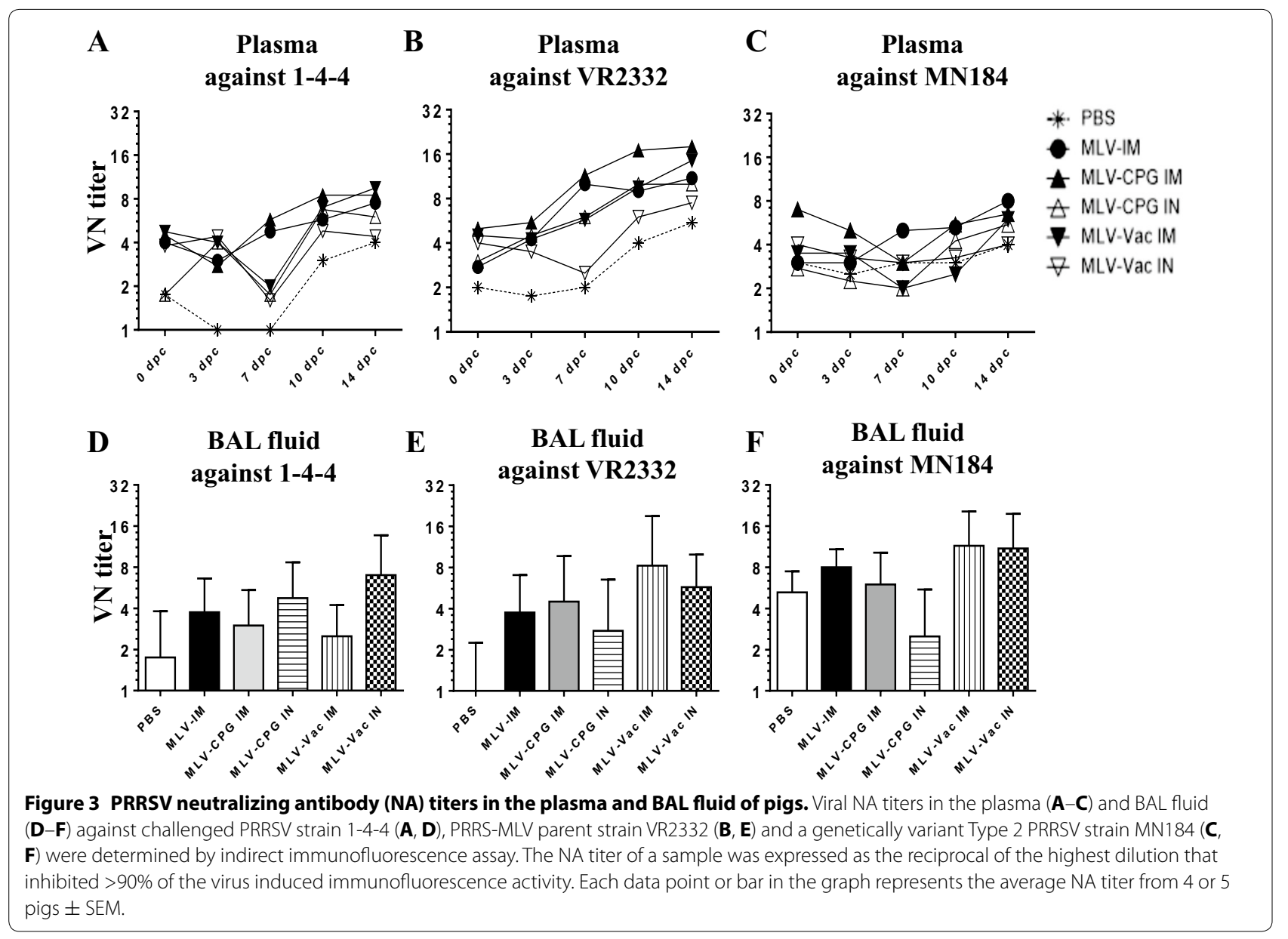

We previously demonstrated that pigs immunized with PRRS-MLV with $M$. $t b$ WCL IN elicit cross-protective response against a heterologous PRRSV strain MN184, which also has 15\% nucleotide difference in GP5 sequence compared to VR2332 [16]. In this study, our results indicated that PRRS-MLV IM with and without adjuvant received pigs had 1-2 log reduced challenged viral RNA compared to IN route vaccinated animals. Further, in all the IM vaccinated pigs the replicating challenged virus was absent at 7,10 and $14 \mathrm{dpc}$ in plasma and also in BAL fluid at $14 \mathrm{dpc}$. Immunologically, these results were supported with NA titers of $>1: 8$ against the strain 1-4-4 in IM vaccinated pigs. This data was consistent with an earlier study wherein PRRSV NA titer of 1:8 or higher protects piglets against development of viremia [41, 42]. In this study, IM vaccinated pigs with a single dose of PRRS-MLV had partial protection to a heterologous challenge virus. Similar degree of partial protection was observed in a heterologous challenge study using a highly pathogenic PRRSV strain JX143 derived PRRS-MLV vaccinated pigs [43].

The protective response against PRRSV in PRRS-MLV vaccinated pigs was found to be dependent more on the levels of cell-mediated than humoral immunity [44]. In pigs vaccinated intranasally using PRRS-MLV and a potent adjuvant, $M . t b$ WCL substantially increased IFN- $\gamma$ response associated with a greater than two-fold increase in the population of CD4 CD8 double positive $\mathrm{T}$ cells (T-helper/memory) in virus-challenged pigs [16]. In pigs vaccinated with an inactivated PRRSV delivered through a biodegradable nanoparticle, the frequency of IFN- $\gamma^{+} \mathrm{CD} 4, \mathrm{CD} 8$ and $\gamma \delta \mathrm{T}$ cell subsets were significantly enhanced and they were correlated well with the clearance of a heterologous challenged virus from the blood 


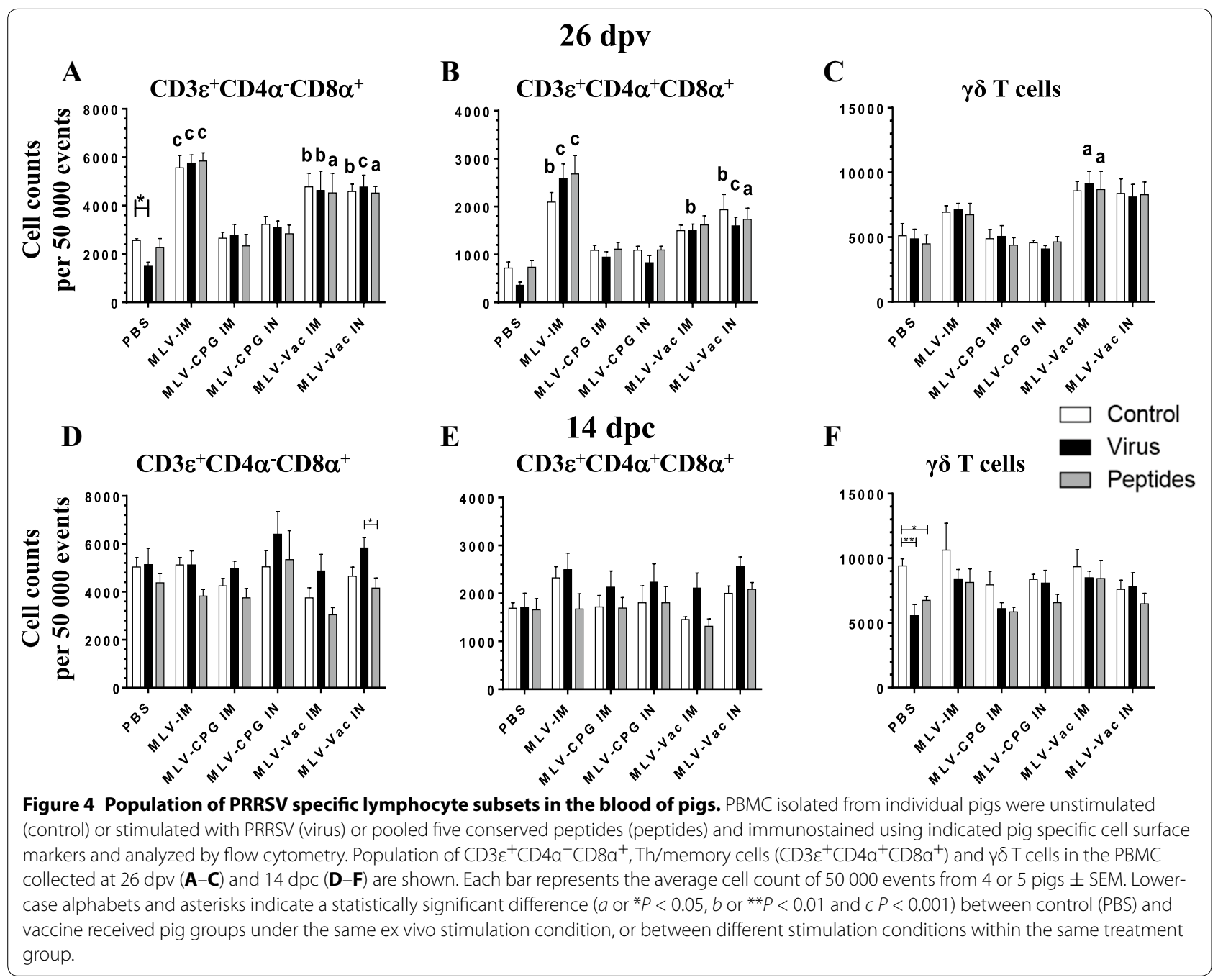

and lungs $[33,38]$. This suggested a strong association of PRRSV clearance to IFN- $\gamma^{+} \mathrm{T}$ cell response, and therefore in this study we determined the population of various IFN- $\gamma$ positive $T$ cell subsets. In pigs, the CD4 CD8 double positive $\mathrm{T}$ cell was shown to possess memory and $\mathrm{T}$ helper phenotype, and upregulation of this activated $\mathrm{T}$ cell subset correlated strongly with the protective immune response against classical swine fever, Aujeszky's disease and PRRSV [38, 45-47]. In PRRS-MLV (without adjuvant) IM received pigs, a significantly increased population of activated $\left(\mathrm{IFN}-\gamma^{+}\right)$CD4 CD8 double positive T cell was observed.

In addition, in pigs $\mathrm{CD} 3 \varepsilon^{+} \mathrm{CD} 4 \alpha^{-} \mathrm{CD} 8 \alpha^{+}$bearing $\mathrm{T}$ cell is either a CTL or a $\gamma \delta \mathrm{T}$ cell, while the cell having the $\mathrm{CD} 3 \varepsilon^{+} \mathrm{CD} 4 \alpha^{-} \mathrm{CD} 8 \alpha \beta^{+}$phenotype is exclusively the CTL [48]. In PRRS-MLV IM (no adjuvant) vaccinated pigs, enhanced population of a $\mathrm{T}$ cell bearing $\mathrm{CD} 3 \varepsilon^{+} \mathrm{CD} 4 \alpha^{-} \mathrm{CD} 8 \alpha^{+}$phenotypic marker was detected at $26 \mathrm{dpv}$; and activated IFN- $\gamma^{+} \mathrm{CD} 3 \varepsilon^{+} \mathrm{CD} 4 \alpha^{-} \mathrm{CD} 8 \alpha^{+}$ and $\gamma \delta \mathrm{T}$ cells were detected in virus challenged pigs at $14 \mathrm{dpc}$. In addition, an upregulated IFN $-\gamma^{+} \mathrm{NK}$ cell population was observed. The recall activated lymphocyte response was detected using the challenged PRRSV, but not with pooled conserved five peptides of Type 2 PRRSV of both structural and non-structural proteins [29-31], suggesting that in our study tested peptides may not be highly immunogenic in pigs. Overall, increased population of activated $\left(\mathrm{IFN}-\gamma^{+}\right) \mathrm{T}$ cell subsets 




in PRRS-MLV IM received pig groups compared to IN delivery was observed. However, due to low NA titers in the IM vaccinated pigs, the $\mathrm{T}$ cell response data alone may not suggest the heightened heterologous protective response.

Both route of vaccination and administration of immunomodulators must be considered in improving vaccine immunity [49]. Aase et al. [50] report that IM immunization with meningococcal outer membrane vesicles in humans has induced significant IgG response, opsonophagocytic activity and serum bactericidal activity compared to IN group; but IN immunization with $10 \times$ more vaccine antigen induced persistent mucosal and systemic antibody responses with antibacterial activity. In conclusion, until we identify a cost-effective potent adjuvant which has potent adjuvant effects akin to $M$. $t b \mathrm{WCL}$, it is beneficial to use PRRS-MLV by IM route; which is currently practiced in most of the swine producing countries to control PRRS inspite of its ability to induce limited cross-protection. 


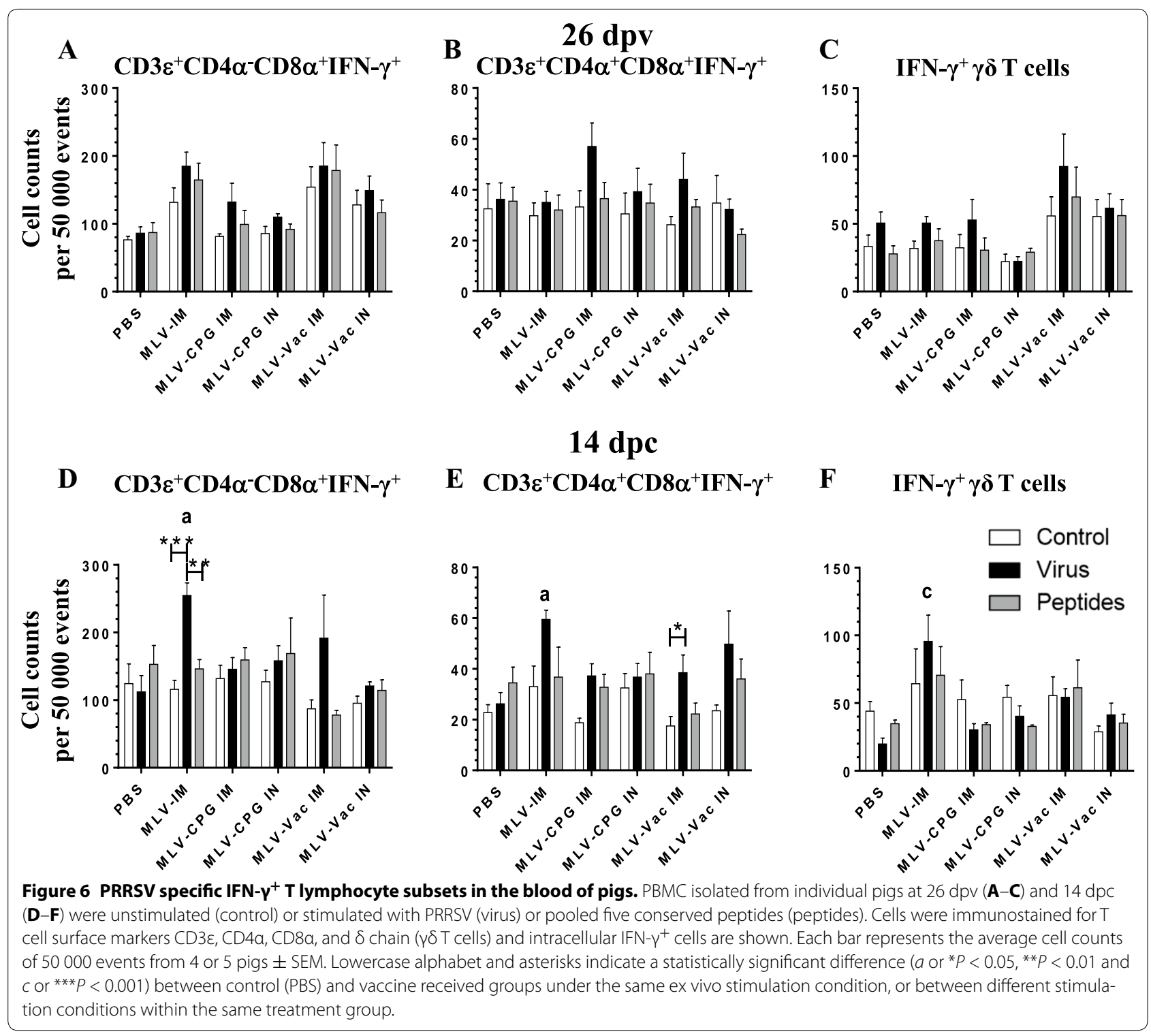

\section{Competing interests}

The authors declare that they have no competing interests.

\section{Author details}

${ }^{1}$ Food Animal Health Research Program (FAHRP), OARDC, Department of Veterinary Preventive Medicine, The Ohio State University, Wooster, $\mathrm{OH}$ 44691, USA. ${ }^{2}$ College of Animal Science and Technology, Guangxi University, Nanning, China. ${ }^{3}$ Department of Microbial Infection and Immunity, The Ohio State University, Columbus, OH, USA. ${ }^{4}$ Kalmbach Swine Management, L.L.C., Upper Sandusky, OH 43351, USA. ${ }^{5}$ Boehringer Ingelheim Vetmedica, Inc., Ames, IA, USA.

\section{Authors' contributions}

$\mathrm{KO}$ performed the experiments, analysis of data (including statistical analysis) and drafted the manuscript. JH, BB, D-LS, SD and RS performed the experiments. JA, LH, MR, and JBT provided the reagents exclusively for this research. GJR performed the experiments, analysis of data and finalized the manuscript. All authors read and approved the final manuscript.

\section{Acknowledgements}

This project was supported by USDA-AFRI. Salaries and research support were provided by state and federal funds appropriated to OARDC. We acknowledge Dr Mike Murtaugh (University of Minnesota) for reagents. Dr Juliette Hanson provided help in animal studies.

Received: 22 October 2015 Accepted: 29 January 2016

Published online: 17 March 2016

\section{References}

1. Neumann EJ, Kliebenstein JB, Johnson CD, Mabry JW, Bush EJ, Seitzinger AH, Green AL, Zimmerman JJ (2005) Assessment of the economic impact of porcine reproductive and respiratory syndrome on swine production in the United States. J Am Vet Med Assoc 227:385-392

2. Holtkamp DJ, Kliebenstein JB, Neumann EJ, Zimmerman JJ, Rotto HF, Yoder TK, Wang C, Yeske PE, Mowrer CL, Haley CA (2013) Assessment of 
the economic impact of porcine reproductive and respiratory syndrome virus on United States pork producers. J Swine Health Prod 21:72-84

3. Collins JE, Benfield DA, Christianson WT, Harris L, Hennings JC, Shaw DP, Goyal SM, McCullough S, Morrison RB, Joo HS, Gorcyca D, Chladek D (1992) Isolation of swine infertility and respiratory syndrome virus (isolate ATCC VR-2332) in North America and experimental reproduction of the disease in gnotobiotic pigs. J Vet Diagn Invest 4:117-126

4. Wensvoort G, Terpstra C, Pol JM, ter Laak EA, Bloemraad M, de Kluyver EP, Kragten C, van Buiten L, den Besten A, Wagenaar F, Broekhuijsen JM, Moonen PL, Zetstra T, de Boer EA, Tibben HJ, de Jong MF, van't Veld P, Greenland GJ, van Gennep JA, Voets MT, Verheijden JH, Braamskamp J (1991) Mystery swine disease in The Netherlands: the isolation of lelystad virus. Vet Q 13:121-130

5. Conzelmann KK, Visser N, Van Woensel P, Thiel HJ (1993) Molecular characterization of porcine reproductive and respiratory syndrome virus, a member of the arterivirus group. Virology 193:329-339

6. Shi M, Lam TT, Hon CC, Murtaugh MP, Davies PR, Hui RK, Li J, Wong LT, Yip CW, Jiang JW, Leung FC (2010) Phylogeny-based evolutionary, demographical, and geographical dissection of North American type 2 porcine reproductive and respiratory syndrome viruses. J Virol 84:8700-8711

7. Ellingson JS, Wang Y, Layton S, Ciacci-Zanella J, Roof MB, Faaberg KS (2010) Vaccine efficacy of porcine reproductive and respiratory syndrome virus chimeras. Vaccine 28:2679-2686

8. Linhares DC, Cano JP, Wetzell T, Nerem J, Torremorell M, Dee SA (2012) Effect of modified-live porcine reproductive and respiratory syndrome virus (PRRSv) vaccine on the shedding of wild-type virus from an infected population of growing pigs. Vaccine 30:407-413

9. Charerntantanakul W (2012) Porcine reproductive and respiratory syndrome virus vaccines: immunogenicity, efficacy and safety aspects. World J Virol 1:23-30

10. Renukaradhya GJ, Meng XJ, Calvert JG, Roof M, Lager KM (2015) Inactivated and subunit vaccines against porcine reproductive and respiratory syndrome: current status and future direction. Vaccine 33:3065-3072

11. Labarque G, Van Gucht S, Van Reeth K, Nauwynck H, Pensaert M (2003) Respiratory tract protection upon challenge of pigs vaccinated with attenuated porcine reproductive and respiratory syndrome virus vaccines. Vet Microbiol 95:187-197

12. Renukaradhya GJ, Meng XJ, Calvert JG, Roof M, Lager KM (2015) Live porcine reproductive and respiratory syndrome virus vaccines: current status and future direction. Vaccine 33:4069-4080

13. Lycke N (2012) Recent progress in mucosal vaccine development: potential and limitations. Nat Rev Immunol 12:592-605

14. Kamijuku H, Nagata Y, Jiang X, Ichinohe T, Tashiro T, Mori K, Taniguchi M, Hase K, Ohno H, Shimaoka T, Yonehara S, Odagiri T, Tashiro M, Sata T, Hasegawa H, Seino KI (2008) Mechanism of NKT cell activation by intranasal coadministration of alpha-galactosylceramide, which can induce cross-protection against influenza viruses. Mucosal Immunol 1:208-218

15. Guillonneau C, Mintern JD, Hubert FX, Hurt AC, Besra GS, Porcelli S, Barr IG, Doherty PC, Godfrey DI, Turner SJ (2009) Combined NKT cell activation and influenza virus vaccination boosts memory CTL generation and protective immunity. Proc Natl Acad Sci U S A 106:3330-3335

16. Dwivedi V, Manickam C, Patterson R, Dodson K, Murtaugh M, Torrelles JB, Schlesinger LS, Renukaradhya GJ (2011) Cross-protective immunity to porcine reproductive and respiratory syndrome virus by intranasal delivery of a live virus vaccine with a potent adjuvant. Vaccine 29:4058-4066

17. Dormitzer PR, Galli G, Castellino F, Golding H, Khurana S, Del Giudice G, Rappuoli R (2011) Influenza vaccine immunology. Immunol Rev 239:167-177

18. Skinner MA, Prestidge R, Yuan S, Strabala TJ, Tan PL (2001) The ability of heat-killed Mycobacterium vaccae to stimulate a cytotoxic T-cell response to an unrelated protein is associated with a 65 kilodalton heat-shock protein. Immunology 102:225-233

19. Dlugovitzky D, Bottasso O, Dominino JC, Valentini E, Hartopp R, Singh M, Stanford C, Stanford J (1999) Clinical and serological studies of tuberculosis patients in Argentina receiving immunotherapy with Mycobacterium vaccae (SRL 172). Respir Med 93:557-562

20. Bode C, Zhao G, Steinhagen F, Kinjo T, Klinman DM (2011) CpG DNA as a vaccine adjuvant. Expert Rev Vaccines 10:499-511

21. Pinzon-Charry A, McPhun V, Kienzle V, Hirunpetcharat C, Engwerda C, McCarthy J, Good MF (2010) Low doses of killed parasite in CpG elicit vigorous CD4+ T cell responses against blood-stage malaria in mice. J Clin Invest 120:2967-2978

22. Malyala P, Chesko J, Ugozzoli M, Goodsell A, Zhou F, Vajdy M, O'Hagan DT, Singh M (2008) The potency of the adjuvant, CpG oligos, is enhanced by encapsulation in PLG microparticles. J Pharm Sci 97:1155-1164

23. Dory D, Beven V, Torche AM, Bougeard S, Cariolet R, Jestin A (2005) CpG motif in ATCGAT hexamer improves DNA-vaccine efficiency against lethal Pseudorabies virus infection in pigs. Vaccine 23:4532-4540

24. Van der Stede Y, Verdonck F, Vancaeneghem S, Cox E, Goddeeris BM (2002) CpG-oligodinucleotides as an effective adjuvant in pigs for intramuscular immunizations. Vet Immunol Immunopathol 86:31-41

25. Kim HS, Kwang J, Yoon IJ, Joo HS, Frey ML (1993) Enhanced replication of porcine reproductive and respiratory syndrome (PRRS) virus in a homogeneous subpopulation of MA-104 cell line. Arch Virol 133:477-483

26. Dwivedi V, Manickam C, Binjawadagi B, Renukaradhya GJ (2013) PLGA nanoparticle entrapped killed porcine reproductive and respiratory syndrome virus vaccine helps in viral clearance in pigs. Vet Microbiol 166:47-58

27. Han J, Wang Y, Faaberg KS (2006) Complete genome analysis of RFLP 184 isolates of porcine reproductive and respiratory syndrome virus. Virus Res 122:175-182

28. Shi L, Torrelles JB, Chatterjee D (2008) Lipoglycans of Mycobacterium tuberculosis: isolation, purification, and characterization. In: Parish T, Brown CA (eds) Mycobacteria protocols, 2nd edn. Humana Press, Totowa, pp 23-45

29. Parida R, Choi IS, Peterson DA, Pattnaik AK, Laegreid W, Zuckermann FA, Osorio FA (2012) Location of T-cell epitopes in nonstructural proteins 9 and 10 of type-II porcine reproductive and respiratory syndrome virus. Virus Res 169:13-21

30. Vashisht K, Goldberg TL, Husmann RJ, Schnitzlein W, Zuckermann FA (2008) Identification of immunodominant T-cell epitopes present in glycoprotein 5 of the North American genotype of porcine reproductive and respiratory syndrome virus. Vaccine 26:4747-4753

31. Diaz I, Pujols J, Ganges L, Gimeno M, Darwich L, Domingo M, Mateu $E$ (2009) In silico prediction and ex vivo evaluation of potential T-cell epitopes in glycoproteins 4 and 5 and nucleocapsid protein of genotypeI (European) of porcine reproductive and respiratory syndrome virus. Vaccine 27:5603-5611

32. Manickam C, Dwivedi V, Patterson R, Papenfuss T, Renukaradhya GJ (2013) Porcine reproductive and respiratory syndrome virus induces pronounced immune modulatory responses at mucosal tissues in the parental vaccine strain VR2332 infected pigs. Vet Microbiol 162:68-77

33. Binjawadagi B, Dwivedi V, Manickam C, Ouyang K, Torrelles JB, Renukaradhya GJ (2014) An innovative approach to induce cross-protective immunity against porcine reproductive and respiratory syndrome virus in the lungs of pigs through adjuvanted nanotechnology-based vaccination. Int J Nanomed 9:1519-1535

34. Christopher-Hennings J, Holler LD, Benfield DA, Nelson EA (2001) Detection and duration of porcine reproductive and respiratory syndrome virus in semen, serum, peripheral blood mononuclear cells, and tissues from Yorkshire, Hampshire, and Landrace boars. J Vet Diagn Invest 13:133-142

35. Ouyang K, Binjawadagi B, Kittawornrat A, Olsen C, Hiremath J, Elkalifa N, Schleappi R, Wu J, Zimmerman J, Renukaradhya GJ (2013) Development and validation of an assay to detect porcine reproductive and respiratory syndrome virus-specific neutralizing antibody titers in pig oral fluid samples. Clin Vaccine Immunol 20:1305-1313

36. Vicetti Miguel RD, Maryak SA, Cherpes TL (2012) Brefeldin A, but not monensin, enables flow cytometric detection of interleukin-4 within peripheral T cells responding to ex vivo stimulation with Chlamydia trachomatis. J Immunol Methods 384:191-195

37. Lamoreaux L, Roederer M, Koup R (2006) Intracellular cytokine optimization and standard operating procedure. Nat Protoc 1:1507-1516

38. Binjawadagi B, Dwivedi V, Manickam C, Ouyang K, Wu Y, Lee LJ, Torrelles JB, Renukaradhya GJ (2014) Adjuvanted poly(lactic-co-glycolic) acid nanoparticle-entrapped inactivated porcine reproductive and respiratory syndrome virus vaccine elicits cross-protective immune response in pigs. Int J Nanomed 9:679-694 
39. Wesley RD, Mengeling WL, Lager KM, Clouser DF, Landgraf JG, Frey ML (1998) Differentiation of a porcine reproductive and respiratory syndrome virus vaccine strain from North American field strains by restriction fragment length polymorphism analysis of ORF 5. J Vet Diagn Invest 10:140-144

40. Larochelle R, D'Allaire S, Magar R (2003) Molecular epidemiology of porcine reproductive and respiratory syndrome virus (PRRSV) in Quebec. Virus Res 96:3-14

41. Lopez OJ, Oliveira MF, Garcia EA, Kwon BJ, Doster A, Osorio FA (2007) Protection against porcine reproductive and respiratory syndrome virus (PRRSV) infection through passive transfer of PRRSV-neutralizing antibodies is dose dependent. Clin Vaccine Immunol 14:269-275

42. Renukaradhya GJ, Dwivedi V, Manickam C, Binjawadagi B, Benfield D (2012) Mucosal vaccines to prevent porcine reproductive and respiratory syndrome: a new perspective. Anim Health Res Rev 13:21-37

43. Wei Z, Zhang J, Zhuang J, Sun Z, Gao F, Yuan S (2013) Immunization of pigs with a type 2 modified live PRRSV vaccine prevents the development of a deadly long lasting hyperpyrexia in a challenge study with highly pathogenic PRRSV JX143. Vaccine 31:2062-2066

44. Zuckermann FA, Garcia EA, Luque ID, Christopher-Hennings J, Doster A, Brito M, Osorio F (2007) Assessment of the efficacy of commercial porcine reproductive and respiratory syndrome virus (PRRSV) vaccines based on measurement of serologic response, frequency of gamma-IFN-producing cells and virological parameters of protection upon challenge. Vet Microbiol 123:69-85
45. De Bruin TG, Van Rooij EM, De Visser YE, Bianchi AT (2000) Cytolytic function for pseudorabies virus-stimulated porcine CD4+ CD8dull+ lymphocytes. Viral Immunol 13:511-520

46. Saalmuller A, Werner T, Fachinger $V$ (2002) T-helper cells from naive to committed. Vet Immunol Immunopathol 87:137-145

47. Franzoni G, Kurkure NV, Edgar DS, Everett HE, Gerner W, Bodman-Smith KB, Crooke HR, Graham SP (2013) Assessment of the phenotype and functionality of porcine CD8T cell responses following vaccination with live attenuated classical swine fever virus (CSFV) and virulent CSFV challenge. Clin Vaccine Immunol 20:1604-1616

48. Talker SC, Kaser T, Reutner K, Sedlak C, Mair KH, Koinig H, Graage R, Viehmann M, Klingler E, Ladinig A, Ritzmann M, Saalmuller A, Gerner W (2013) Phenotypic maturation of porcine NK- and T-cell subsets. Dev Comp Immunol 40:51-68

49. Sasaki S, Hamajima K, Fukushima J, Ihata A, Ishii N, Gorai I, Hirahara F, Mohri H, Okuda K (1998) Comparison of intranasal and intramuscular immunization against human immunodeficiency virus type 1 with a DNA-monophosphoryl lipid A adjuvant vaccine. Infect Immun $66: 823-826$

50. Aase A, Naess LM, Sandin RH, Herstad TK, Oftung F, Holst J, Haugen IL, Hoiby EA, Michaelsen TE (2003) Comparison of functional immune responses in humans after intranasal and intramuscular immunisations with outer membrane vesicle vaccines against group B meningococcal disease. Vaccine 21:2042-2051

\section{Submit your next manuscript to BioMed Central and we will help you at every step:}

- We accept pre-submission inquiries

- Our selector tool helps you to find the most relevant journal

- We provide round the clock customer support

- Convenient online submission

- Thorough peer review

- Inclusion in PubMed and all major indexing services

- Maximum visibility for your research

Submit your manuscript at www.biomedcentral.com/submit

() Biomed Central 